\title{
ECONOMICS
}

\section{TIERED GASOLINE PRICING: A PERSONAL CARBON TRADING PERSPECTIVE}

\author{
by \\ Yao Li, \\ Jin Fan, \\ Dingtao Zhao \\ School of Management \\ University of Science and Technology of China \\ Yanrui Wu \\ Business School \\ University of Western Australia \\ and \\ Jun Li \\ School of Management, \\ University of Science and Technology of China
}




\title{
TIERED GASOLINE PRICING: A PERSONAL CARBON TRADING PERSPECTIVE
}

\author{
Yao $\mathrm{Li}^{\mathrm{a}}$, Jin $\mathrm{Fan}^{\mathrm{a} *}$, Dingtao Zhao ${ }^{\mathrm{a}}$, Yanrui $\mathrm{Wu}^{\mathbf{b}}$, Jun $\mathrm{Li}^{\mathrm{a}}$ \\ a School of Management, University of Science and Technology of China, P.R. China \\ b Business School, University of Western Australia, Australia
}

\section{DISCUSSION PAPER 16.02}

Forthcoming in Energy Policy

\begin{abstract}
This paper proffers a tiered gasoline pricing (TGP) method from a personal carbon trading (PCT) perspective. An optimization model of personal carbon trading is proposed, and then, an equilibrium carbon price is derived according to the market clearing condition. Based on the derived equilibrium carbon price, this paper proposes a calculation method of tiered gasoline pricing. Then, sensitivity analyses and consumers' surplus analyses are conducted. It can be shown that a rise in gasoline price or a more generous allowance allocation would incur a decrease in the equilibrium carbon price, making the first tiered price higher, but the second tiered price lower. It is further verified that the proposed tiered pricing method is progressive because it would relieve the pressure of the low-income groups who consume less gasoline while imposing a greater burden on the high-income groups who consume more gasoline. Based on these results, implications, limitations and future studies are provided.
\end{abstract}

Keywords: Tiered gasoline pricing; Optimization model; Personal carbon trading; Sensitivity analysis; Progressivity 


\section{Introduction}

Carbon emissions in the Chinese transportation sector contributed to $12 \%$ of the total emissions in 2012 (NBSC, 2013). More than half of these transportation carbon emissions are related to private vehicles. From 2004 to 2014, motor vehicle ownership rose by approximately 1.5 times, as the Traffic Management Bureau of Ministry of Public Security of China announced ${ }^{1}$. Private vehicles are always labeled for safety, comfort, reliability and flexibility. However, these vehicles may have other unfavorable consequences, such as noise, congestion, accidents and air pollution (Verhoef, 1994; Santos et al., 2010).

Therefore, several regulation policies have been proposed to alleviate environmental impacts and achieve transportation sustainability. In the transportation sector, most environmental problems result from the heavy dependence on fossil fuel, such as gasoline and diesel (Yin et al., 2015). Currently, the policies mainly cover travel demand management, which focuses either on quantity or price instruments (Yang and Wang, 2011). There is currently a trial implementation of restrictions on auto purchases or uses in certain pilot cities in China. For example, in Shanghai, new private vehicle license plates have been restricted to certain numbers and have been issued by public auction since 2000 (People’s Congress of Shanghai, 2000). In addition, several other cities, such as Beijing, Shenzhen and Hangzhou, issued license-plate lottery policies in succession to inhibit the explosive growth of private vehicles ${ }^{2}$.

1 See http://www.mps.gov.cn/n16/n85753/n4449431/4473813.html.

2 See http://epaper.chinadailyasia.com/asia-weekly/article-3962.html. 
These measures alleviate the transportation problems to an extent. However, such quantity-based policies may lead to a sharp increase of old, cheap and high-polluting second-hand car consumption in the long term (Mahendra, 2008). This possibility is also consistent with the conclusion of Davis (2008) that drivers in Mexico tended to buy more polluting cars to circumvent the number plate restriction. Moreover, a carbon or fuel tax is a type of price instrument that regulates vehicle fuel demand. However, the tax policy is regressive among consumers and is difficult for the public to accept (Callan et al., 2009; Fan et al., 2015b).

To promote a sustainable and green consumption mode, a tiered gasoline pricing mechanism was proffered in the Clean Air Act of 2013 to 2017 that was released by Chinese government on February $14^{\text {th }}, 2014$. Similar to the tiered water or electricity pricing policy, tiered gasoline pricing is a multi-step pricing mechanism in which the gasoline price will be low for consumption until a certain threshold value is reached, whereas any consumption exceeding this value will be charged a higher price (Lin and Jiang, 2012). In the non-target subsidies mechanism, the vehicle owners who over-consume gasoline would enjoy subsidies from those who under-consume, which would eventually lead to aggregate welfare losses (Lin et al., 2009; Sun and Lin, 2013). Therefore, the current non-target subsidy mechanism is not consistent with social equity and energy sustainability. The target subsidy mechanism, for instance, tiered pricing, is expected to be a solution to address these concerns.

In this paper, we propose a tiered gasoline pricing mechanism from a personal carbon trading (PCT) perspective and investigate its distributional effect. A PCT 
scheme is defined as a mixed quantity and price instrument to begin translating the consumption perspective to carbon abatement practice (Fleming, 1996). The scheme is a downstream "cap-and-trade” mechanism that strives to reduce carbon emissions from the household sector, which is extended from the upstream emissions trading scheme in the industrial sector (Fleming, 1996; Fawcett, 2010; Xu et al., 2015). Under a PCT scheme, consumers would be allocated fixed carbon allowances, which are consistent with the reduction goal. These carbon allowances are used to cover the emissions associated with the consumption of energy commodities, such as gasoline and electricity (Howell, 2012; Raux et al., 2015). The over-emitters who emit more than their allowance allocation must buy allowances for surrender from the market, whereas the under-emitters who emit less than their allowance allocation could sell the extra allowances (Cohen, 2011). Consumers under a PCT scheme would be burdened with the additional cost of carbon emissions, which may lay the basis for the calculation of tiered pricing.

The remainder of this paper is organized as follows. Section 2 introduces the tiered pricing mechanism and justifies the personal carbon trading perspective. Section 3 constructs a basic optimization model of personal carbon trading and derives a formula for tiered gasoline pricing. Section 4 describes the parameter values and presents the calculation results of a specific tiered pricing mechanism on the selected samples collected from 4 s shops in China. Section 5 provides an extensive discussion of sensitivity analyses and consumers' welfare analyses. Section 6 concludes with findings, limitations and future studies. 


\section{Tiered pricing and PCT}

In China, there has been widespread focus on tiered pricing in the electricity and water sectors. The tiered pricing mechanism divides consumption into several blocks, and a certain price is applied to a defined block (Lin and Liu, 2013). Previous research studies indicate that a tiered pricing mechanism has several advantages over a traditional flat pricing mechanism (Sun and Lin, 2013; Schoengold and Zilberman, 2014). The implementation of a tiered pricing regime would reduce electricity consumption (Du et al., 2015). Moreover, a reasonable tariff structure in the electricity sector would promote consumers to reduce carbon emissions and seek energy-efficient products (Haney et al., 2009). Most importantly, tiered pricing for household electricity (TPHE) would contribute to the achievement of the twin objectives of efficiency and equity (Sun, 2015). In addition, advances in electronic metering technology and the experiences of a tiered pricing regime in the electricity and water sectors in some of China's pilot provinces have raised prospects for the implementation of tiered gasoline pricing in the transportation sector.

Many researches on tiered pricing mechanisms focus on the public acceptance, equity analysis and impacts on energy saving (Wang et al., 2012; He et al., 2014; Schoengold and Zilberman, 2014). Additionally, scholars undertake these analyses based on a given tiered pricing policy. For instance, Monteiro (2011) conducted an efficiency analysis under a presetting increasing block tariff structure. Du et al. (2015) investigated the feedback of household electricity consumption to the new tiered pricing policy based on micro-level household data. Hung and Huang (2015) 
estimated the dynamic demand for residential electricity in Taiwan under a given increasing block pricing policy. However, these studies ignore the specific calculation of tiered pricing, such as how to divide consumption into several blocks and how to determine the price to apply to each defined block. Others develop their research on the Ramsey pricing rule. For instance, Boiteux (1956) applied the Ramsey-Botieux inverse elasticity pricing rule to price the products of public utilities, such as power and water. Furthermore, Kim (1995) formulated a tiered pricing mechanism based on the marginal cost pricing and inverse elasticity pricing rules in the water sector. Sun and Lin (2013) proffered three proposals of Chinese residential electricity tariffs according to the coverage of different consumption groups and conducted a sensitivity test using empirical data to check the robustness.

These researches applied the Ramsey pricing rule to determine the tiered price at which the price markup is inverse to the price elasticity in each income group (Chattopadhyay, 2004). It is indicated that income growth actually has a direct impact on vehicle ownership, whereas income variation has not played a significant role in greatly influencing the exact gasoline demand (Newman and Kenworthy, 1989; Dargay et al., 2007). Thus, gasoline demand is not as sensitive to income, making the adoption of the Ramsey pricing rule for gasoline pricing not justifiable. More attention has been attracted to the severity of carbon emissions in the gasoline consumption of cars, which necessitates a new perspective of considering the environmental externalities. Generally, for gasoline-fueled vehicle types, there is a linear relation between gasoline consumption and the associated carbon emissions 
(Hoen et al., 2013); this means that the more one drives, the more emissions one will generate. According to the Polluter Pays Principle (OECD, 1972), vehicle owners who emit more should pay more. Therefore, to be consistent with the goal of carbon abatement, it is vital to design a policy instrument to internalize carbon externalities in the formulation of the tiered pricing.

A PCT scheme offers a potentially powerful and innovative instrument with which to deliver demanding reductions in carbon emissions (Bristow et al., 2010). Several studies prove that a PCT scheme is technically and institutionally feasible (Starkey, 2012; Raux et al., 2015; Fan et al., 2015a). Moreover, the PCT scheme is a progressive system that would help to achieve income redistribution between the under-emitters and over-emitters (Parag and Eyre, 2010; Li et al., 2014). Allowances would transfer from the under-emitters to the over-emitters, and wealth would, in turn, transfer from the over-emitters to the under-emitters. Therefore, the PCT scheme could not only internalize the environmental externalities but could be capable of providing abatement certainty and redistributing income between the rich and the poor (Fan et al., 2015b). Thus, this paper attempts to propose the calculation method of tiered gasoline pricing from a PCT perspective.

\section{Model formulation}

In this section, the tiered pricing method will be developed on the basis of the equilibrium carbon price under a PCT scheme. An optimization model is proposed, and then, an equilibrium carbon price is derived from the market clearing condition. 
Subsequently, the specific tiered price could be determined.

\subsection{Optimization model}

The optimization model is based on the utility theory of consumer choice that a consumer would make decisions upon consumption bundles to achieve utility maximization (Houthakker, 1950). With the rapid process of urbanization in China, vehicle consumption is playing a significant role in daily life. In most households, consumers would make a trade-off between expenditures on vehicles and other consumption goods (Greening et al., 2000). For simplicity, this paper considers that a consumer would be confronted with consumption decisions on vehicle miles traveled and the other consumption goods. The PCT scheme is proposed to regulate the personal carbon emissions aroused from the household sector, such as electricity consumption, and personal travel (Fawcett, 2004; Aziz et al., 2015). Among the energy carriers, the demand elasticity of fuel is relatively larger than that of electricity (Ramanathan, 1999). Thus the PCT scheme is more capable of providing abatement certainties in the transportation sector. Therefore, we begin by considering the transport-generated carbon emissions that are first to be capped and regulated by the PCT scheme. Here, transport consumptions exclusively refer to private motorized car mileages because public transportation or transit and non-motorized transportation produce less carbon emissions, which are excluded from the PCT scheme (Bottrill, 2006; Vespermann and Wald, 2011). Because carbon emissions are measurable with a certain degree of accuracy (Stephen, 1992), we only consider the externality of carbon 
emissions in gasoline consumption, ignoring other externalities in vehicle travel, such as noise and traffic accidents, which can be observed in Parry and Small (2005) and Parry (2009).

It is natural to assume that consumers who drive private motorized vehicles should participate in the PCT scheme. This paper assumes that there are $m$ over-emitters and $n$ under-emitters distinguished by their gasoline consumption in driving. Under such a scheme, consumers are not only subject to a money budget but also carbon allocation when they drive cars. The rationale for an allowance allocation is critical in the PCT scheme. Most authors focused on the egalitarian principle of equity, which is inspired by the international carbon reduction proposal "contraction and convergence”, that is, everyone has an equal right to emit greenhouse gases (Meyer, 2000; Fawcett, 2004; Wadud, 2011). Thus, an equal per capital allowance allocation is assumed as the starting point.

Under the PCT scheme, each over-emitter $i$ who emits more than allowance allocation $\omega$ must purchase allowances $\psi_{i}$ for surrender from carbon market, and vice versa, each under-emitter $j$ who emits less could sell allowances $\psi_{j}$. Consumers are assumed to be price-takers, and they maximize their utility function $U$ defined over the vehicle miles traveled $x$ and other consumption goods $y$. $x$ would emit carbon emissions directly. As previously noted, other consumption goods $y$ will not cost allowances because most researchers suggest that the PCT scheme should first cover the transport-generated carbon emissions (Wadud, 2011; Raux et al., 2015). Moreover, the indirect carbon emissions from goods $y$ are difficult to track and 
measure and are excluded from the PCT scheme (Eyre, 2010). Assuming that the utility function $u$ takes the form of Cobb-Douglas function $x^{\alpha} y^{1-\alpha}$, given that the consumer choice models with the Cobb-Douglas utility function are simple and tractable, it generates clear and testable empirical predictions (Rosenzweig and Schultz, 1983; Heffetz, 2007). The parameters $\alpha$ and $1-\alpha$ represent the expenditure share of vehicle miles traveled and other consumption goods, respectively (Mankiw, 1998). Symbolically,

$U(x, y)=x^{\alpha} y^{1-\alpha}$

s.t. $\left\{\begin{array}{c}p_{x} x+p_{y} y+p_{c} \psi \leq I\left(\text { shadow price } \phi_{1}\right) \\ e \lambda x-\psi \leq \omega\left(\text { shadow price } \phi_{2}\right)\end{array}\right.$

where $p_{x}$ denotes the mileage price; $p_{x} x+p_{y} y$ denotes the expenditure on the vehicle miles traveled and the other consumption goods; and $p_{c} \psi$ denotes the expenditure or gain of allowance trading. The budget requires that the total expenditure should be less than the income $I . e \lambda x-\psi$ denotes the final carbon emissions through carbon trading, which should be less than the allowance budget $\omega$. If $\psi<0$, the consumer is an under-emitter; otherwise, the consumer is an over-emitter. The shadow prices, $\phi_{1}$ and $\phi_{2}$, are defined as the marginal changes in the objective function with respect to an increase in the right-side of the constraint conditions. All of the parameters and variables are expressed in per-capita-per-year term, and the notations are provided in Table 1.

$<$ Table 1 is here $>$ 
According to the Karush-Kuhn-Tucker (KKT), the problem (1) is a linear program whose optimality condition is

$$
\begin{aligned}
& 0 \leq x \perp \alpha x^{\alpha-1} y^{1-\alpha}-\phi_{1} p_{x}-\phi_{2} e \lambda_{i} \geq 0 \\
& 0 \leq y \perp(1-\alpha) x^{\alpha} y^{-\alpha}-\phi_{1} p_{y} \geq 0 \\
& 0 \leq \phi_{1} \perp p_{x} x+p_{y} y+p_{c} \psi_{i}-I \geq 0 \\
& 0 \leq \phi_{2} \perp e \lambda x-\psi-\omega \geq 0 \\
& 0 \leq \psi_{i} \perp-\phi_{1} p_{c}+\phi_{2} \geq 0
\end{aligned}
$$

where $\perp$ indicates orthogonality between two vectors, which, in this case, express the complementary slackness condition in linear programming (Zhao et al., 2010; Chen et al., 2011).

According to equations (1) and (2), the allowances traded by the under-emitter and the over-emitter are as follows,

$$
\begin{aligned}
& \psi_{i}=\frac{\alpha e \lambda_{i} I_{i}-\omega p_{x}-\omega(1-\alpha) p_{c} e \lambda_{i}}{e \lambda_{i} p_{c}+p_{x}} \\
& \psi_{j}=\frac{\omega p_{x}+\omega(1-\alpha) p_{c} e \lambda_{j}-\alpha e \lambda_{i} I_{j}}{e \lambda_{j} p_{c}+p_{x}}
\end{aligned}
$$

where $\psi_{i}$ and $\psi_{j}$ represent the supply function and the demand function in the allowance market.

\subsection{Market clearing condition}

For a market with numerous sellers and buyers, the total supply and demand function is approximately a continuous curve and could be derived from the individual supply and demand function (Mas-Colell et al., 1995; Jiang, 2006). This paper assumes that the aggregate consumers would choose a mix of different car types with an average mileage price $\overline{p_{x}}$ and gasoline consumption per mile $\lambda$. Therefore, 
according to equations (3) and (4), the total supply and demand functions of multiple consumers can be summarized as follows:

$D=\frac{\lambda e \alpha \sum_{i=1}^{m} I_{i}+m \omega \alpha e \lambda p_{c}}{e \lambda p_{c}+\overline{p_{x}}}-m \omega$

$S=n w-\frac{n \omega \alpha e \lambda^{\prime} p_{c}+\lambda^{\prime} \alpha e \sum_{j=1}^{n} I_{j}}{e \lambda^{\prime} p_{c}+\overline{p_{x}}}$

where $\mathrm{D}$ and $\mathrm{S}$ are the total demand curve and the total supply curve, respectively. According to the market clearing condition $(D=S)$, the equilibrium price is

$p_{c}=\frac{\frac{\lambda e \alpha}{(n+m)}\left(\sum_{i=1}^{m} I_{i}+\sum_{i=1}^{n} I_{j}\right)-\omega \overline{p_{x}}}{\omega e \lambda(1-\alpha)}$

\subsection{Formula of tiered pricing}

In the PCT scheme, consumers must pay a price of $p_{c}$ for carbon emissions. The under-emitters would be subsidized due to the extra allowances sold in the market, whereas the over-emitters must buy allowances for surrender, resulting in a discriminated actual gasoline cost among consumers. This finding agrees with the principle of a tiered pricing mechanism in which a price will be lower for consumption until reaching a certain threshold, whereas any consumption exceeding this threshold will be charged a higher price. For simplicity, this paper considers a two-tiered structure of gasoline pricing. The total expenditure under a tiered pricing mechanism can be formulated as follows: 
$C(Q)=\left\{\begin{array}{lr}p_{1} Q & Q \leq Q^{*} \\ p_{1} Q^{*}+p_{2}\left(Q-Q^{*}\right) & Q \geq Q^{*}\end{array}\right.$

where $C(Q)$ is the expenditure on gasoline consumption; $Q^{*}$ is the threshold of gasoline consumption, which distinguishes whether a consumer is an over-emitter or an under-emitter; and $p_{i}$ is the actual gasoline price on the $i$ th block. In the zero-profit equilibrium, the first tiered price $p_{1}$ in equation (8) is determined by the average cost of under-emitters. The second tiered price $p_{2}$ in equation (8) denotes the actual cost of gasoline consumption, which exceeds the $Q^{*}$ of over-emitters. This price is determined by the ratio of the total expenditure on gasoline consumption that exceeds the threshold relative to the corresponding consumption amount of the over-emitters. The first and second tiered prices can be expressed as follows,

$p_{1}=\frac{\sum_{i}^{m}\left[p_{f} Q_{L i}-\left(\omega-Q_{L i} e\right) p_{c}\right]}{\sum_{i}^{m} Q_{L i}}$, for each $Q_{L i}<Q^{*}$

$p_{2}=\frac{\sum_{j}^{n}\left[p_{f} Q_{H j}-Q^{*} p_{1}+\left(Q_{H j} e-\omega\right) p_{c}\right]}{\sum_{j}^{n}\left(Q_{H j}-Q^{*}\right)}$, for each $Q_{H j}>Q^{*}$

where $Q_{L i}$ and $Q_{H j}$ represent the gasoline consumption of under-emitter $i$ and over-emitter $j$, respectively. In equation (9), the total cost for an under-emitter $i$ equals the expenditure on gasoline consumption $p_{f} Q_{L i}$ minus the gain from selling the extra allowances $\left(\omega-Q_{L i} e\right) p_{c}$. In equation (10), the actual cost of the gasoline consumption, which exceeds the $Q^{*}$ of an over-emitter $j$, equals the expenditure on gasoline consumption $\left(p_{f} Q_{H j}\right)$ minus the expenditure on the consumption below $Q^{*}$ paid at a price of $p_{1}\left(Q^{*} p_{1}\right)$ and plus the expenditure of buying allowances for surrender 
$\left(\left(Q_{H j} e-\omega\right) p_{c}\right)$

\section{Data and results}

This section uses sampled data as an example to illustrate the calculation of the specific tiered pricing. We collected approximately 3,620 items of vehicle owners' travel information from 2008 to 2013 from 4s shops in China, which include different vehicle parameters (vehicle brand, vehicle model, official guiding price, and displacement), vehicle miles traveled each year, maintenance costs, and household income ranges. Additionally, the data of gasoline consumption per mile are sourced from the Ministry of Industry and Information Technology (MIIT) of the People's Republic China to calculate the exact vehicle emissions ${ }^{3}$. Other data are from China Statistical Yearbook 2008-2013 ${ }^{4}$

In the zero-profit equilibrium, vehicle mileage costs are obtained by summing the gasoline cost (FC), maintenance cost (MC) and levelized cost (LC, vehicle purchasing cost shared by year). According to İşlegen (2011), $C / \sum_{t=1}^{T} \gamma^{t}$ is the levelized cost of the vehicle during its service life $T$ and $\gamma \equiv 1 /(1+r)$. Let $C$ denote the vehicle purchase cost and $r$ is the current interest rate of $3 \%{ }^{5}$. As regulated by Standard of Automobile Scrapping, the standard retirement life of private vehicles (including sedan and cross-country type) with 9 seats or less is 15 years ${ }^{6}$. Thus, $T$ is assumed to be 15 years. Then, the detailed formula to estimate the average

\footnotetext{
${ }^{3}$ See http://chinaafc.miit.gov.cn/.

${ }^{4}$ See http://www.stats.gov.cn/tjsj/ndsj/.

${ }^{5}$ See http://data.bank.hexun.com/ll/ckll.aspx.

${ }^{6}$ See http://www.zhb.gov.cn/gkml/hbb/gwy/201301/t20130115_245171.htm.
} 
mileage price is as follows,

$$
\overline{p_{x}}=\frac{1}{m+n} \sum_{i}^{m+n} \frac{M C_{i}+F C_{i}+L C_{i}}{x}
$$

where $M C_{i}, F C_{i}$ and $L C_{i}$ denote the maintenance cost, gasoline cost and levelized cost of vehicle owner $i$, respectively. From the survey data, the average maintenance cost is $\$ 573.83$ per year. The gasoline cost can be calculated by multiplying the mileage consumption and the gasoline consumption per mile and the gasoline price. The current price of gasoline is approximately $4.62 \$ /$ gallon in China ${ }^{7}$. According to equation (11), the average mileage price is $\overline{p_{x}}=1.42 \$$ /gallon.

According to Mankiw (1998), $\alpha$ in the above utility function represents the expenditure share of vehicle miles traveled. The average expenditure share of the 3,620 items is adopted given that the aggregate data would satisfy the Generalized Axiom of Revealed Preference (Varian, 1990). As indicated by the survey data, the vehicle owners belong to middle-income groups or above with a household average annual disposable income of $\$ 14,607.2$. The average expenditure on total vehicle miles traveled is approximately $\$ 7,947.14$. The data calculation implies that $\alpha=0.544$.

In the proposed tiered pricing, the threshold value would be influenced by allowance allocation and the gasoline emission rate. The allowance allocation is determined by political and institutional decisions on the overall cap stringency, which relates to the emission abatement goal. As is proposed in Energy Saving and Emission Reduction for Highway and Waterway Transportation in the $12^{\text {th }}$ Five Year

\footnotetext{
${ }^{7}$ See http://www.cngold.org/crude/qiyou.html.
} 
Plan, China committed to reach a 40\%-45\% emission reduction goal by $2020^{8}$. Thus, the allowance allocation is set to be $2,200 \mathrm{~kg}$, which is consistent with the carbon abatement goal; furthermore, it satisfies the condition that $\psi_{i}, \psi_{j}>0$. Then, we have $Q^{*}=\omega / e=237.57$ gallon as the threshold in the tiered pricing. According to the parameter settings and equation (7), we obtain $p_{c}=0.16 \$ / \mathrm{kg}$. Based on the survey data, the overall samples are classified into two groups, under-emitters and over-emitters, according to the threshold $Q^{*}$. In each group, the consumers' actual gasoline cost is calculated using equations (9) and (10); therefore, $p_{1}=3.89 \$ /$ gallon and $p_{2}=6.44 \$$ /gallon, respectively. Then, the expenditure under the benchmark parameters is formulated as follows,

$$
C(Q)= \begin{cases}3.89 Q & Q \leq 223.57 \\ 3.89 Q^{*}+6.44\left(Q-Q^{*}\right) & Q \geq 223.57\end{cases}
$$

where $Q^{*}=237.57$ gallon.

Therefore, a consumer would be charged a price of 3.89\$/gallon when he consumes less than 223.57 gallons, and any consumption exceeding this threshold would be charged at a higher price of $6.44 \$$ /gallon. As determined, this threshold value, equivalent to 14.9 miles of car driving every day, is reasonable, which approximately guarantees a commuter's daily driving in China. In the current pricing mechanism of the Chinese power sector, the gap between each tiered price is so small that consumers are insensitive to the price change, which significantly affects the effectiveness of this mechanism (Lin and Jiang, 2012). Furthermore, Agthe and

\footnotetext{
${ }^{8}$ See http://www.moc.gov.cn/zhuzhan/zhengcejiedu/guihuajiedu/shierwuguihuaJD/xiangguanzhengcefagui/2 01110/t20111010_1064457.html.
} 
Billings (1987) suggested that it is better to widen the gaps in the tiered pricing because the equity will be improved. In this pricing mechanism, the gap between each tiered price achieves as much as $\$ 2.55$ per gallon.

\section{Discussion}

This section conducts sensitivity analyses to discuss how this tiered pricing mechanism would respond to different parameter values. Then, welfare changes under the proposed pricing mechanism are analyzed to examine the progressivity.

\subsection{Sensitivity analyses}

The gasoline price in China decreased dramatically by $30 \%$ in the past year ${ }^{9}$. Previous studies argued that the introduction of PCT is capable of stabilizing consumers' actual gasoline cost (Wadud, 2011; Fan et al., 2015b). Thus, it is vital to investigate how the first and the second tiered price in the proposed pricing method would respond to the original gasoline price. Moreover, allowance allocation is a critical factor in the policy design of a PCT scheme, which would affect the perceived fairness and carbon abatement effect (Bristow et al, 2010). The allowance allocation indicates the emission cap stringency (Starkey, 2012). The tiered pricing policy should be aligned with the emission target each year. Therefore, it is essential to conduct sensitivity analysis to examine how the two tiered pricing would respond to the allowance allocation changes. These two critical parameters are listed as follows:

\footnotetext{
${ }^{9}$ See http://www.tradingeconomics.com/china/gasoline-prices.
} 
(1) $p_{f}$, original gasoline price, which indicates the price trend of energy market, and (2) $\omega$, allowance allocation, indicating the emission target. When a relatively stringent (generous) emission target is chosen, the regulatory department must issue fewer (more) carbon allowances.

First, as shown in Table 2, when the original gasoline price increases, ceteris paribus, the first tiered price will increase, whereas the second tiered price will decrease. Table 2 indicates upward adjustments in the gasoline price of 5.0\% to $15.0 \%$, resulting in a rise in the first tiered price from $11.8 \%$ to $35.5 \%$ and a fall in the second tiered price from $-5.3 \%$ to $-15.7 \%$; consequently, there is a sharp decrease in the price gap from $-31.4 \%$ to $-100.0 \%$. Conversely, downward adjustments in the gasoline price from $-5 \%$ to $-15 \%$ lead to a fall in the first tiered price of $-11.8 \%$ to $-35.2 \%$ and a rise in the second tiered price from $5.3 \%$ to $16.0 \%$. Furthermore, the price gap would become more obvious, a rise from $31.4 \%$ to $94.1 \%$.

When the gasoline price rises (falls), the equilibrium carbon price would be lower (higher). Therefore, the under-emitters would reduce the (more) subsidies, and the over-emitters would pay fewer (more) dollars, resulting in a higher (lower) first tiered price but a lower (higher) second tiered price. The implication is that the regulatory department should raise (lower) the first tiered price and reduce (raise) the second tiered price when the gasoline price goes up (goes down). Moreover, more attention should focus on the price gap between the first and the second tiered price, which would affect the public perceived equity towards the policy design, as indicated by Whittington (1992). 
$<$ Table 2 is here $>$

Second, the tiered prices would be susceptible to the allowance allocation. As is shown in Table 3, a small change in the allowance allocation would arouse great changes in the first and second tiered prices and particularly the price gap. Downward adjustments in the allowance allocation from $-2.5 \%$ to $10.0 \%$ lead to a sharp decrease in the first tiered price from $-23.7 \%$ to $-99.7 \%$ and a large rise in the second tiered price from $44.4 \%$ to $146.3 \%$. Additionally, the price gap would be five times as wide as that of the baseline scenario.

Equation (7) indicates that with a lower carbon allowance allocation, the carbon price would increase. Therefore, the under-emitters would be subsidized for selling extra allowances, leading to a lower first tiered price, whereas the over-emitters would be confronted with a higher gasoline price. Consumers would be confronted with a more obvious price gap with a more stringent carbon abatement goal and vice versa. Accordingly, the price gap would be set in accordance with the emission target in the policy design. Thus, the regulatory government should reduce (raise) the first tiered price and raise (lower) the second tiered price when a relatively (less) stringent carbon abatement goal is required.

$<$ Table 3 is here $>$

\subsection{Consumers' welfare change analyses}

This section will investigate the welfare changes under this two-tiered pricing 
mechanism and examine the progressivity of this mechanism. The consumer surplus is used to measure the welfare changes by calculating the difference between what a consumer is willing to pay and what he actually pays (Quartey and Yarney et al., 2013). The change in consumer surplus ( $\Delta C S$ ) can be calculated based on the price changes due to tiered pricing as follows:

$$
\Delta C S=\int_{p_{0}}^{p^{\prime}} Q(p) d p
$$

where $Q(p)$ is the Marshallian demand function, $p$ 'is the actual gasoline price and $p_{0}$ is the original gasoline price. According to equations (A7), (A11), (A12) and (A13), we have the Marshallian demand function of an under-emitter $\left(Q_{i}\right)$ as follows by substituting $x \lambda$ with $x_{f}$ and $\left(p_{f}+e p_{c}\right)$ with $p$,

$$
Q_{i}=\frac{\alpha\left(\bar{I}-I_{i}\right)}{p}+\frac{\omega}{e}
$$

Similarly, the Marshallian demand function of an over-emitter $\left(Q_{j}\right)$ is

$$
Q_{j}=\frac{\alpha\left(I_{j}-\bar{I}\right)}{p}+\frac{\omega}{e}
$$

Based on equation (13), the welfare change of the under-emitter $\left(\triangle C S_{i}\right)$ and the over-emitter $\left(\triangle C S_{j}\right)$ are as follows,

$$
\begin{aligned}
& \Delta C S_{i}=\alpha\left(\bar{I}-I_{i}\right) \ln \frac{p_{f}}{p_{1}}+\frac{\omega}{e}\left(p_{f}-p_{1}\right) \\
& \Delta C S_{j}=\int_{p_{1}}^{p_{f}} Q^{*} d p-\int_{p_{f}}^{p_{2}}\left(Q_{j}-Q^{*}\right) d p=\frac{\omega}{e}\left(p_{f}-p_{1}\right)-\alpha\left(I_{j}-\bar{I}\right) \ln \frac{p_{2}}{p_{f}}
\end{aligned}
$$

The under-emitter $i$ would gain welfare change $\Delta C S_{i}$ for the price reduction. However, the over-emitter $j$ 's welfare change would depend on the absolute value of the welfare gain due to the price decrease from $p_{f}$ to $p_{1}$ for consumption below $Q^{*}$ 
and the welfare loss due to the price increase from $p_{f}$ to $p_{2}$ for consumption above $Q^{*}$. According to the China Statistical Yearbook 2014, the per capita disposable income in the urban setting is divided into 5 groups. Thus, the under-emitters and over-emitters could be discriminated based on the boundary condition $I^{*}=\$ 2,312.75$ derived from equations (A12) and (A13); their consumer surplus changes are presented as follows in Table 4.

$<$ Table 4 is here $>$

Consumers in the first twenty percent income group, with an average income of $\$ 1,871.31$, would garner a welfare change of 437.03 due to the gasoline price decrease from 4.62\$/gallon to 3.89\$/gallon. The over-emitters are charged for a lower price for consumption below $Q^{*}$ and a higher price for consumption above $Q^{*}$; therefore, they do not always suffer from welfare loss. As indicated in Fig. 4, consumers in the second, third, and fourth twenty percent would gain a positive welfare change because the welfare gain would dominate the welfare loss. Although the consumers whose income falls in the last twenty percent would suffer a total welfare loss as the welfare loss dominates the welfare gain. The welfare loss would increase when the average income increases. Table 4 indicates that there is a "subsidies leakage” (Lin and Jiang, 2012) in the second, third and fourth income groups, which deserves attention in the policy design.

Figs. 1 and 2 are presented to gain intuitive insight into the consumers' surplus 
changes. We choose the average income level of the first twenty percent and the last twenty percent income group as the baseline income of the under-emitters and the over-emitters, respectively. Then, we investigate how the consumer surplus change responds to an income increase or decrease of ten percent.

$<$ Fig. 1 is here $>$

$<$ Fig. 2 is here $>$

Fig. 1 indicates that the under-emitters would always be better off. When the under-emitters are poorer, they would be subsidized more in this pricing mechanism, which would intensify their perception of fairness. For the over-emitters, the higher income group would suffer more welfare loss (Fig. 2). Therefore, the tiered pricing mechanism is progressive by redistributing income between the poor and the rich (Parag and Eyre, 2010). This finding is consistent with the studies of Hajispyrou et al. (2002) and Porcher (2014) on the tiered pricing mechanism in the water sector. Generally, high income groups would consume more gasoline than low income groups. The welfare analysis implies that a tiered gasoline pricing policy would be a feasible policy option to achieve equity and gain public acceptance.

\section{Conclusions}

This paper attempts to propose a tiered gasoline pricing method from a PCT perspective. We calculate the specific tiered gasoline pricing based on survey data 
from the Chinese transportation sector. Sensitivity analyses are conducted to investigate the impacts of the original gasoline prices and initial allowance allocation on the tiered pricing. Then, consumers' welfare changes are analyzed to investigate the progressivity of this pricing method.

It is shown that the under-emitters and over-emitters under a PCT scheme would be burdened with a different unit cost of gasoline, which is consistent with the principle of tiered pricing (Lin and Jiang, 2012). According to the estimations, the threshold of the tiered pricing is 223.57 gallon and the first and the second tiered prices are 3.89\$/gallon and 6.44\$/gallon, respectively. That is, when one consumes below this threshold, one would be charged a price of $3.89 \$ /$ gallon, whereas consumption exceeding this threshold would be charged $6.44 \$$ gallon. Different parameter settings indicate that gasoline prices and allowance allocation have a large bearing on tiered pricing, but with different directions. A rise in gasoline prices would incur a decrease in the equilibrium carbon price, making the first tiered price higher but the second tiered price lower. With a more stringent (generous) allowance allocation, the carbon price would increase (decrease); thus, the first tiered price will decrease (increase). However, the second tiered price will increase (decrease). Furthermore, although a "subsidy leakage" exists, the proposed tiered pricing mechanism would relieve the pressure of the low-income groups who consume less gasoline while imposing a greater burden on the high-income groups who consume more. Therefore, this pricing mechanism is progressive in general.

These findings have several policy implications. First, the proposed tiered 
gasoline pricing mechanism also holds the assumption that low income groups are also low gasoline consumers (Filipovic' and Tanic', 2009). Although there is an exception that several low income groups live on shipping-related jobs would easily fall into the higher tier, thus being burdened with high expenditures on gasoline. Certain preferential treatment could be practiced by the regulatory department, such as subsidies (Fawcett, 2010). Currently, in China, the per capital gasoline consumption is relatively low; however, it is rapidly growing. The tiered pricing policy should be a dynamic adjustment mechanism that incorporates several elements, such as the crude oil price, overall emission cap stringency and per capital gasoline consumption. Policy makers should vary the tiered prices with the original gasoline price and emission target. When the original gasoline price rises, the first tiered price should be adjusted upward, whereas the second one should be adjusted downward. Additionally, when the carbon reduction goal becomes more stringent, the second tiered price should be adjusted sharply upward, whereas the first could be adjusted slightly downward. Moreover, consistent with other studies in the tiered pricing mechanism (Diakité et al., 2009; Lin and Jiang, 2012), the implementation of the proposed tiered pricing policy is capable of distributing wealth between the rich and the poor, which is in accordance with the initial objective of energy price reform. The policy strengthens public perceived equity and heightens public acceptance. This policy mechanism is of vital significance to advance energy pricing reform in China.

However, this study is only an initial study on the rising pricing reform from a PCT perspective. Many further research studies for comprehensive considerations are 
needed. For instance, we consider a two-tiered structure as a preliminary solution in the tariff design, which can be extended to a multi-tiered one, given the basic, average and extravagant needs of gasoline consumption. These considerations would help this pricing design to step closer to reality.

\section{Appendix}

This appendix provides a formal derivation of the allowance trading amount. The process of derivation is expressed as follows:

$$
\begin{aligned}
& 0 \leq x \perp \alpha x^{\alpha-1} y^{1-\alpha}-p_{x} \phi_{1}-e \lambda_{i} \phi_{2} \geq 0 \\
& 0 \leq y \perp(1-\alpha) x^{\alpha} y^{-\alpha}-\phi_{1} p_{y} \geq 0 \\
& 0 \leq \psi_{i} \perp-\phi_{1} p_{c}+\phi_{2} \geq 0 \\
& 0 \leq \phi_{1} \perp p_{x} x+p_{y} y+p_{c} \psi_{i}-I \geq 0 \\
& 0 \leq \phi_{2} \perp e \lambda x-\psi-\omega \geq 0
\end{aligned}
$$

According to the Karush-Kuhn-Tucker (KKT) optimality conditions (A.1) and (A.2), we obtain

$$
\frac{y}{x}=\frac{(1-\alpha)\left(p_{x}+p_{c} e \lambda_{i}\right)}{\alpha p_{y}}
$$

From equations (A.4) and (A.5), we obtain

$$
\begin{aligned}
& x=\frac{\psi+\omega}{e \lambda_{i}} \\
& y=\frac{-p_{x} x-p_{c} \psi+I}{p_{y}}
\end{aligned}
$$

Substituting equations (A.8) into (A.6), we obtain 
$x=\frac{\alpha\left(I-p_{c} \psi_{i}\right)}{p_{x}+(1-\alpha) p_{c} e \lambda_{i}}$

From equation (A.3), we obtain

$-p_{c} \phi_{1}+\phi_{2}=0$

Substituting equations (A.7), (A.8) and (A.9) into equation (A.6), we have

$\psi_{i}=\frac{\alpha e \lambda_{i} I_{i}-\omega p_{x}-\omega(1-\alpha) p_{c} e \lambda_{i}}{e \lambda_{i} p_{c}+p_{x}}$

If $\psi>0$, the quantity of allowance purchased by over-emitter is

$\psi_{i}=\frac{\alpha e \lambda_{i} I_{i}-\omega p_{x}-\omega(1-\alpha) p_{c} e \lambda_{i}}{e \lambda_{i} p_{c}+p_{x}}$

If $\psi<0$, the quantity of allowance sold by under-emitter is

$\psi_{j}=\frac{\omega p_{x}+\omega(1-\alpha) p_{c} e \lambda_{i}-\alpha e \lambda_{i} I_{j}}{e \lambda_{i} p_{c}+p_{x}}$

\section{Acknowledgements}

The authors are grateful to the National Natural Science Foundation of China (71301157, 71571172) for their generous financial support. They also acknowledge the editor and anonymous referees of the journal for their careful reading and constructive comments. 


\section{References}

Agthe, D.E, Billings, R.B., 1987. Equity, price elasticity, and household income under increasing block rates for water. American Journal of Economics and Sociology 46 (3), 273-286.

Aziz, H.A., Ukkusuri, S.V., Romero, J., 2015. Understanding short-term travel behavior under personal mobility credit allowance scheme using experimental economics. Transportation Research Part D: Transport and Environment 36, 121-137.

Baiardi, D., Menegatti, M., 2011. Pigouvian tax, abatement policies and uncertainty on the environment. Journal of Economics 103(3), 221-251.

Boiteux, M., 1956. Sur la gestion des monopoles publics astreints à l'équilibre budgétaire. Econometrica, Journal of the Econometric Society 24, 22-40.

Bottrill, C., 2006. Personal Carbon Trading: Excluding Public Transportation. Environmental Change Institute, Oxford.

Bristow, A.L., Wardman, M., Zanni, A.M., Chintakayala, P.K., 2010. Public acceptability of personal carbon trading and carbon tax. Ecological Economics 69(9), 1824-1837.

Callan, T., Lyons, S., Scott, S., Tol, R.S., Verde, S., 2009. The distributional implications of a carbon tax in Ireland. Energy Policy 37(2), 407-412.

Chattopadhyay, P., 2004. Cross-subsidy in electricity tariffs: evidence from India. Energy Policy 32(5), 673-684.

Chen, Y, Liu, A.L, Hobbs, B.F., 2011. Economic and emissions implications of 
load-based, source-based, and first-seller emissions trading programs under California AB32. Operations Research 59, 696-712.

Cohen, M.J., 2011. Is the UK preparing for “war”? Military metaphors, personal carbon allowances, and consumption rationing in historical perspective. Climatic Change 104 (2), 199-222.

Dargay, J, Gately, D, Sommer, M., 2007. Vehicle ownership and income growth, worldwide: 1960-2030. The Energy Journal 28 (4), 143-170.

Davis, L.W., 2008. The effect of driving restrictions on air quality in Mexico City. Journal of Political Economy 116 (1), 38-81.

Diakité, D., Semenov, A., Thomas, A., 2009. A proposal for social pricing of water supply in Côte d'Ivoire. Journal of Development Economics 88(2), 258-268.

Du, G., Lin, W., Sun, C., Zhang, D., 2015. Residential electricity consumption after the reform of tiered pricing for household electricity in China. Applied Energy 157, 276-283.

Eyre, N., 2010. Policing carbon: design and enforcement options for personal carbon trading. Climate Policy 10(4), 432-446.

Fan, J., Li, Y., Wu, Y.R., Wang, S.Y, Zhao, D.T., 2015a. Allowance trading and energy consumption under a personal carbon trading scheme: a dynamic programming approach. Journal of Cleaner Production. doi:10.1016/j.jclepro.2015.07.030.

Fan, J, Wang, S.Y, Wu, Y.R, Li, J, Zhao, D.T, 2015b. Buffer effect and price effect of a personal carbon trading scheme. Energy 82, 601-610.

Fawcett, T., 2004. Carbon rationing and personal energy use. Energy and Environment 15(6), 1067-1083. 
Fawcett, T., 2010. Personal carbon trading: a policy ahead of its time? Energy Policy 38(11), 6868-6876.

Fleming, D., 1996. Stopping the traffic. Country Life 140(19), 62-65.

Filipovic', S., Tanic', G., 2009. The policy of consumer protection in the electricity

Market. Economic Annals 53(178-179), 157-182.

Greening, L.A., Greene, D.L., Difiglio, C., 2000. Energy efficiency and consumption — the rebound effect—a survey. Energy Policy 28(6), 389-401

Hajispyrou, S., Koundouri, P., Pashardes, P., 2002. Household demand and welfare: implications of water pricing in Cyprus. Environment and Development Economics 7(4), 659-685.

Haney, B, Jamasb, T, Pollitt, M.G., 2009. Smart metering and electricity demand: technology, economics and international experience. Working paper, Cambridge.

He, Y., Liu, Y., Wang, J., Xia, T., Zhao, Y., 2014. Low-carbon-oriented dynamic optimization of residential energy pricing in China. Energy 66, 610-623.

Heffetz, O., 2007. Cobb-Douglas utility with nonlinear Engel curves in a conspicuous consumption model. Available at SSRN 1004544.

Hoen, K.M, Tan, T, Fransoo, J.C, van Houtum, G.J., 2013. Switching transport modes to meet voluntary carbon emission targets. Transportation Science 48(4), 592-608.

Houthakker, H.S., 1950. Revealed preference and the utility function. Economica 17(66), 159-174.

Howell, R.A., 2012. Living with a carbon allowance: the experiences of Carbon 
Rationing Action Groups and implications for policy. Energy Policy 41, 250-258.

Hung, M.F., Huang, T.H., 2015. Dynamic demand for residential electricity in Taiwan under seasonality and increasing-block pricing. Energy Economics 48, 168-177.

İşlegen, Ö, Reichelstein, S., 2011. Carbon capture by fossil fuel power plants: an economic analysis. Management Science 57(1), 21-39.

Jiang, D.C., 2006. Advanced Microeconomics. Peking University Press.

Kim, H.Y., 1995. Marginal cost and second-best pricing for water services. Review of Industrial Organization 10, 323-338.

Lin, B.Q., Jiang, Z.J., 2012. Designation and influence of household increasing block electricity tariffs in China. Energy Policy 42, 164-173.

Lin, B.Q., Jiang, Z.J., Lin, J., 2009. Targeting electricity tariff subsidy contributes to enhance energy fairness and efficiency. Finance Research 11, 1-18.

Lin, B.Q, Liu, X., 2013. Electricity tariff reform and rebound effect of residential electricity consumption in China. Energy 59, 240-247.

Li, J., Fan, J., Zhao, D.T., Wang, S.Y., 2014. Allowance price and distributional effects under a personal carbon trading scheme. Journal of Cleaner Production 103 (15), 319-329.

Mahendra, A., 2008. Vehicle restrictions in four Latin American cities: is congestion pricing possible? Transport Review 28 (1), 105-133.

Mankiw, N.G., 1988. Imperfect competition and the Keynesian cross. Economics Letters 26(1), 7-13.

Mas-Colell, A, Whinston, M.D, Green, J.R., 1995. Microeconomic theory (Vol. 1). 
New York: Oxford university press.

Meyer, A., 2000. Contraction and convergence: the global solution to climate change. Green Books, Totnes, UK.

Monteiro, H., Roseta - Palma, C., 2011. Pricing for scarcity? An efficiency analysis of increasing block tariffs. Water Resources Research 47. <http://dx.doi.org/10.1029/2010WR009200>

National Bureau of Statistics of China (NBSC), 2013. China Energy Statistical Yearbook. Energy Bureau of Statistics Press and China Statistics Press, Beijing (in Chinese).

Newman, P.W.G, Kenworthy, J.R., 1989. Gasoline consumption and cities. Journal of the American Planning Association 55(1), 24-37.

OECD, 1972. Recommendation on Guiding Principles Concerning International Economic Aspects of Environmental Policies C (72) 128.

Parag, Y., Eyre, N., 2010. Barriers to personal carbon trading in the policy arena. Climate Policy 10(4), 353-368.

Parry, I.W., 2009. How much should highway gasolines be taxed? Available at SSRN 1552184

Parry, I.W, Small, K.A., 2005. Does Britain or the United States have the right gasoline tax? The American Economic Review 95(4), 1276-1289.

People's Congress of Shanghai, 2000. Regulations on administration of motor vehicles in Shanghai, Shanghai, China.

Porcher, S., 2014. Efficiency and equity in two-part tariffs: the case of residential 
water rates. Applied Economics 46(5), 539-555.

Quartey J.D., Yarney N.G., 2013. Ghana's Elmina Beach and economic welfare improvement. Journal of Economics and Sustainable Development 4 (13), 89-96.

Ramanathan, R., 1999. Short-and long-run elasticities of gasoline demand in India: An empirical analysis using cointegration techniques. Energy Economics 21(4), 321-330.

Raux, C., Croissant, Y., Pons, D., 2015. Would personal carbon trading reduce travel emissions more effectively than a carbon tax? Transportation Research Part D: Transport and Environment 35, 72-83.

Rosenzweig, M.R, Schultz, T.P., 1983. Estimating a household production function: Heterogeneity, the demand for health inputs, and their effects on birth weight. The Journal of Political Economy 91(5), 723-746.

Santos, G, Behrendt, H, Maconi, L, Shirvani, T, Teytelboym, A., 2010. Part I: externalities and economic policies in road transport. Research in Transportation Economics 28(1), 2-45.

Schoengold, K., Zilberman, D., 2014. The economics of tiered pricing and cost functions: Are equity, cost recovery, and economic efficiency compatible goals?. Water Resources and Economics 7, 1-18.

Starkey, R., 2012. Personal carbon trading: A critical survey Part 2: Efficiency and effectiveness. Ecological Economics 73, 19-28.

Stephen, F., 1992. Local and global incentives for sustainability: failures in economic 
systems. Ecological economics: the science and management of sustainability 344.

Sun, C., 2015. An empirical case study about the reform of tiered pricing for household electricity in China. Applied Energy, 160, 383-389.

Sun, C, Lin B., 2013. Reforming residential electricity tariff in China: tiered tariffs pricing approach. Energy Policy 60, 741-752.

Varian, HR., 1990. Goodness-of-fit in optimizing models. Journal of Econometrics 46 (1), 125-140.

Verhoef, E., 1994. External effects and social costs of road transport. Transportation Research Part A: Policy and Practice 28(4), 273-287.

Vespermann, J, Wald, A., 2011. Much ado about nothing?-an analysis of economic impacts and ecologic effects of the EU-emission trading scheme in the aviation industry. Transportation Research Part A: Policy and Practice 45(10), 1066-1076.

Wadud, Z., 2011. Personal tradable carbon permits for road transport: why, why not and who wins? Transportation Research Part A: Policy and Practice 45(10), 1052-1065.

Wang, Z., Zhang, B., Zhang, Y., 2012. Determinants of public acceptance of tiered electricity price reform in China: Evidence from four urban cities. Applied Energy 91(1), 235-244.

Whittington, D., 1992. Possible adverse effects of increasing block water tariffs in developing countries. Economic Development and Cultural Change, 75-87.

Xu, J., Yang, X., Tao, Z., 2015. A tripartite equilibrium for carbon emission allowance 
allocation in the power-supply industry. Energy Policy 82, 62-80.

Yang, H, Wang, X., 2011. Managing network mobility with tradable credits. Transportation Research Part B: Methodological 45(3), 580-594.

Yin, X., Chen, W., Eom, J., Clarke, L.E., Kim, S.H., Patel, P.L., Yu, S, Kyle, G.P., 2015. China's transportation energy consumption and $\mathrm{CO}_{2}$ emissions from a global perspective. Energy Policy 82, 233-248.

Zhao, J.Y, Hobbs, B.F, Pang, J.S., 2010. Long-run equilibrium modeling of emissions allowance allocation systems in electric power markets. Operations Research 3, $529-548$. 
Editor, UWA Economics Discussion Papers:

Sam Hak Kan Tang

University of Western Australia

35 Sterling Hwy

Crawley WA 6009

Australia

Email: ecoadmin@biz.uwa.edu.au

The Economics Discussion Papers are available at:

1980 - 2002: http://ecompapers.biz.uwa.edu.au/paper/PDF\%20of\%20Discussion\%20Papers/

Since 2001: $\quad$ http://ideas.repec.org/s/uwa/wpaper1.html

Since 2004: $\quad$ http://www.business.uwa.edu.au/school/disciplines/economics

\begin{tabular}{|c|c|c|}
\hline \multicolumn{3}{|c|}{$\begin{array}{l}\text { ECONOMICS DISCUSSION PAPERS } \\
2015\end{array}$} \\
\hline $\begin{array}{l}\text { DP } \\
\text { NUMBER }\end{array}$ & AUTHORS & TITLE \\
\hline 15.01 & Robertson, P.E. and Robitaille, M.C. & $\begin{array}{l}\text { THE GRAVITY OF RESOURCES AND THE TYRANNY OF } \\
\text { DISTANCE }\end{array}$ \\
\hline 15.02 & Tyers, R. & $\begin{array}{l}\text { FINANCIAL INTEGRATION AND CHINA'S GLOBAL } \\
\text { IMPACT }\end{array}$ \\
\hline 15.03 & Clements, K.W. and Si, J. & $\begin{array}{l}\text { MORE ON THE PRICE-RESPONSIVENESS OF FOOD } \\
\text { CONSUMPTION }\end{array}$ \\
\hline 15.04 & Tang, S.H.K. & $\begin{array}{l}\text { PARENTS, MIGRANT DOMESTIC WORKERS, AND } \\
\text { CHILDREN'S SPEAKING OF A SECOND LANGUAGE: } \\
\text { EVIDENCE FROM HONG KONG }\end{array}$ \\
\hline 15.05 & Tyers, R. & $\begin{array}{l}\text { CHINA AND GLOBAL MACROECONOMIC } \\
\text { INTERDEPENDENCE }\end{array}$ \\
\hline 15.06 & $\begin{array}{l}\text { Fan, J., Wu, Y., Guo, X., Zhao, D. } \\
\text { and Marinova, D. }\end{array}$ & $\begin{array}{l}\text { REGIONAL DISPARITY OF EMBEDDED CARBON } \\
\text { FOOTPRINT AND ITS SOURCES IN CHINA: A } \\
\text { CONSUMPTION PERSPECTIVE }\end{array}$ \\
\hline 15.07 & $\begin{array}{l}\text { Fan, J., Wang, S., Wu, Y., Li, J. and } \\
\text { Zhao, D. }\end{array}$ & $\begin{array}{l}\text { BUFFER EFFECT AND PRICE EFFECT OF A PERSONAL } \\
\text { CARBON TRADING SCHEME }\end{array}$ \\
\hline 15.08 & Neill, K. & $\begin{array}{l}\text { WESTERN AUSTRALIA'S DOMESTIC GAS } \\
\text { RESERVATION POLICY THE ELEMENTAL ECONOMICS }\end{array}$ \\
\hline 15.09 & Collins, J., Baer, B. and Weber, E.J. & THE EVOLUTIONARY FOUNDATIONS OF ECONOMICS \\
\hline 15.10 & $\begin{array}{l}\text { Siddique, A., Selvanathan, E. A. and } \\
\text { Selvanathan, S. }\end{array}$ & $\begin{array}{l}\text { THE IMPACT OF EXTERNAL DEBT ON ECONOMIC } \\
\text { GROWTH: EMPIRICAL EVIDENCE FROM HIGHLY } \\
\text { INDEBTED POOR COUNTRIES }\end{array}$ \\
\hline 15.11 & Wu, Y. & $\begin{array}{l}\text { LOCAL GOVERNMENT DEBT AND ECONOMIC } \\
\text { GROWTH IN CHINA }\end{array}$ \\
\hline 15.12 & Tyers, R. and Bain, I. & $\begin{array}{l}\text { THE GLOBAL ECONOMIC IMPLICATIONS OF FREER } \\
\text { SKILLED MIGRATION }\end{array}$ \\
\hline 15.13 & Chen, A. and Groenewold, N. & $\begin{array}{l}\text { AN INCREASE IN THE RETIREMENT AGE IN CHINA: } \\
\text { THE REGIONAL ECONOMIC EFFECTS }\end{array}$ \\
\hline 15.14 & Knight, K. & PIGOU, A LOYAL MARSHALLIAN? \\
\hline 15.15 & Kristoffersen, I. & $\begin{array}{l}\text { THE AGE-HAPPINESS PUZZLE: THE ROLE OF } \\
\text { ECONOMIC CIRCUMSTANCES AND FINANCIAL } \\
\text { SATISFACTION }\end{array}$ \\
\hline
\end{tabular}




\begin{tabular}{|c|c|c|}
\hline 15.16 & Azwar, P. and Tyers, R. & INDONESIAN MACRO POLICY THROUGH TWO CRISES \\
\hline 15.17 & Asano, A. and Tyers, R. & $\begin{array}{l}\text { THIRD ARROW REFORMS AND JAPAN'S ECONOMIC } \\
\text { PERFORMANCE }\end{array}$ \\
\hline 15.18 & Arthmar, R. and McLure, M. & $\begin{array}{l}\text { ON BRITAIN'S RETURN TO THE GOLD STANDARD: } \\
\text { WAS THERE A 'PIGOU-MCKENNA SCHOOL’? }\end{array}$ \\
\hline 15.19 & $\begin{array}{l}\text { Fan, J., Li, Y., Wu, Y., Wang, S., and } \\
\text { Zhao, D. }\end{array}$ & $\begin{array}{l}\text { ALLOWANCE TRADING AND ENERGY CONSUMPTION } \\
\text { UNDER A PERSONAL CARBON TRADING SCHEME: A } \\
\text { DYNAMIC PROGRAMMING APPROACH }\end{array}$ \\
\hline 15.20 & Shehabi, M. & $\begin{array}{l}\text { AN EXTRAORDINARY RECOVERY: KUWAIT } \\
\text { FOLLOWING THE GULF WAR }\end{array}$ \\
\hline 15.21 & $\begin{array}{l}\text { Siddique, A., Sen, R., and } \\
\text { Srivastava, S. }\end{array}$ & $\begin{array}{l}\text { AUSTRALIA-THAILAND TRADE: AN ANALYSIS OF } \\
\text { COMPETITIVENESS AND THE EFFECTS OF THE } \\
\text { BILATERAL FTA }\end{array}$ \\
\hline 15.22 & Tyers, R. & $\begin{array}{l}\text { SLOWER GROWTH AND VULNERABILITY TO } \\
\text { RECESSION: UPDATING CHINA'S GLOBAL IMPACT }\end{array}$ \\
\hline 15.23 & Arthmar, R. and McLure, M. & PIGOU ON WAR FINANCE AND STATE ACTION \\
\hline 15.24 & Wu, Y. & $\begin{array}{l}\text { CHINA'S CAPITAL STOCK SERIES BY REGION AND } \\
\text { SECTOR }\end{array}$ \\
\hline 15.25 & Clements, K. and Si, J. & $\begin{array}{l}\text { ENGEL'S LAW, DIET DIVERSITY AND THE QUALITY OF } \\
\text { FOOD CONSUMPTION }\end{array}$ \\
\hline 15.26 & Chen, S. & $\begin{array}{l}\text { SHIFTS OF DISTORTION AND CORRUPTION OVER } \\
\text { LOCAL POLITICAL CYCLES IN CHINA }\end{array}$ \\
\hline 15.27 & Chen, S. & $\begin{array}{l}\text { THE EFFECT OF A FISCAL SQUEEZE ON TAX } \\
\text { NFORCEMENT: EVIDENCE FROM A NATURAL } \\
\text { EXPERIMENT IN CHINA }\end{array}$ \\
\hline 15.28 & Jetter, M. & $\begin{array}{l}\text { BLOWING THINGS UP: THE EFFECT OF MEDIA } \\
\text { ATTENTION ON TERRORISM }\end{array}$ \\
\hline 15.29 & Tang, S. & $\begin{array}{l}\text { MEDIUM-TERM MACROECONOMIC VOLATILITY AND } \\
\text { ECONOMIC DEVELOPMENT: A NEW TECHNIQUE }\end{array}$ \\
\hline 15.30 & Alim, A., Hartley, P. and Lan, Y. & $\begin{array}{l}\text { ASIAN SPOT PRICES FOR LNG OTHER ENERGY } \\
\text { COMMODITIES }\end{array}$ \\
\hline 15.31 & $\begin{array}{l}\text { Gannon, B., Harris, D., Harris, M., } \\
\text { Magnusson, L., Hollingsworth, B., } \\
\text { lnder, B., Maitra, P, and Munford, L. }\end{array}$ & $\begin{array}{l}\text { NEW APPROACHES TO ESTIMATING THE CHILD } \\
\text { HEALTH-PARENTAL INCOME RELATIONSHIP }\end{array}$ \\
\hline 15.32 & Czaika, M. and Parsons, C. & $\begin{array}{l}\text { THE GRAVITY OF HIGH SKILLED MIGRATION } \\
\text { POLICIES }\end{array}$ \\
\hline 15.33 & $\begin{array}{l}\text { Parsons, C., Rojon, S., Samanani, F, } \\
\text { and Wettach, L. }\end{array}$ & $\begin{array}{l}\text { CONCEPTUALISING INTERNATIONAL HIGH-SKILLED } \\
\text { MIGRATION }\end{array}$ \\
\hline 15.34 & Chen, S. & $\begin{array}{l}\text { VAT RATE DISPERSION AND TFP LOSS IN CHINA'S } \\
\text { MANUFACTURING SECTOR }\end{array}$ \\
\hline 15.35 & $\begin{array}{l}\text { Tait, L., Siddique, A. and } \\
\text { Chatterjee, I. }\end{array}$ & $\begin{array}{l}\text { FOREIGN AID AND ECONOMIC GROWTH IN } \\
\text { SUB-SAHARAN AFRICA }\end{array}$ \\
\hline
\end{tabular}




\begin{tabular}{|c|c|c|}
\hline \multicolumn{3}{|c|}{$\begin{array}{l}\text { ECONOMICS DISCUSSION PAPERS } \\
2016\end{array}$} \\
\hline $\begin{array}{l}\text { DP } \\
\text { NUMBER }\end{array}$ & AUTHORS & TITLE \\
\hline 16.01 & Xu, R., Wu, Y. and Luan, J. & $\begin{array}{l}\text { ANALYSIS OF FARMERS' WILLINGNESS TO ADOPT } \\
\text { GENETICALLY MODIFIED INSECT-RESISTANT RICE IN } \\
\text { CHINA }\end{array}$ \\
\hline 16.02 & $\begin{array}{l}\text { Lia, Y., Fan, J., Zhao, D., Wu, Y. and } \\
\text { Li, J. }\end{array}$ & $\begin{array}{l}\text { TIERED GASOLINE PRICING: A PERSONAL CARBON } \\
\text { TRADING PERSPECTIVE }\end{array}$ \\
\hline 16.03 & Clements, K.W., Lan, Y. and Si, J. & UNCERTAINTY IN CURRENCY MISPRICING \\
\hline 16.04 & Parsons, C. and Vézina, P.L. & $\begin{array}{l}\text { MIGRANT NETWORKS AND TRADE:THE VIETNAMESE } \\
\text { BOAT PEOPLE AS A NATURAL EXPERIMENT }\end{array}$ \\
\hline 16.05 & Chang, S., Connelly, R. and Ma, P. & $\begin{array}{l}\text { WHAT WILL YOU DO IF I SAY ‘I DO’?: THE EFFECT OF } \\
\text { THE SEX RATIO ON TIME USE WITHIN TAIWANESE } \\
\text { MARRIED COUPLES }\end{array}$ \\
\hline 16.06 & $\mathrm{Yu}, \mathrm{F}$. and $\mathrm{Wu}, \mathrm{Y}$. & $\begin{array}{l}\text { BIASES IN PATENT EXAMINATION AND FIRMS' } \\
\text { RESPONSES: EVIDENCE FROM THE PHARMACEUTICAL } \\
\text { INDUSTRY }\end{array}$ \\
\hline 16.07 & $\begin{array}{l}\text { Fan, J., Li, J., Wu, Y., Wang, S. and } \\
\text { Zhao, D. }\end{array}$ & $\begin{array}{l}\text { THE EFFECTS OF ALLOWANCE PRICE ON ENERGY } \\
\text { DEMAND UNDER A PERSONAL CARBON TRADING } \\
\text { SCHEME }\end{array}$ \\
\hline 16.08 & Golley, J., Tyers, R. and Zhou, Y. & $\begin{array}{l}\text { CONTRACTIONS IN CHINESE FERTILITY AND } \\
\text { SAVINGS: LONG RUN DOMESTIC AND GLOBAL } \\
\text { IMPLICATIONS }\end{array}$ \\
\hline 16.09 & McGrath, G. and Neill, K. & $\begin{array}{l}\text { FOREIGN AND DOMESTIC OWNERSHIP IN WESTERN } \\
\text { AUSTRALIA'S GAS MARKET }\end{array}$ \\
\hline 16.10 & Clements, K.W. and Si, J. & SIMPLIFYING THE BIG MAC INDEX \\
\hline 16.11 & Priyati, R.Y. and Tyers, R. & $\begin{array}{l}\text { PRICE RELATIONSHIPS IN VEGETABLE OIL AND } \\
\text { ENERGY MARKETS }\end{array}$ \\
\hline 16.12 & Wu, J., Wu, Y. and Wang, B. & $\begin{array}{l}\text { THE GREENNESS OF CHINESE CITIES: CARBON } \\
\text { DIOXIDE EMISSION AND ITS DETERMINANTS }\end{array}$ \\
\hline 16.13 & $\begin{array}{l}\text { Arslan, C., Dumont, J.C., Kone, Z., } \\
\text { Özden, Ç., Parsons, C. and } \\
\text { Xenogiani, T. }\end{array}$ & $\begin{array}{l}\text { INTERNATIONAL MIGRATION TO THE OECD IN THE } \\
\text { TWENTY-FIRST CENTURY }\end{array}$ \\
\hline 16.14 & Tomioka, K. and Tyers, R. & $\begin{array}{l}\text { HAS FOREIGN GROWTH CONTRIBUTED TO } \\
\text { STAGNATION AND INEQUALITY IN JAPAN? }\end{array}$ \\
\hline 16.15 & Donovan, J. and Hartley, P. & $\begin{array}{l}\text { RIDING THE IRON ORE CYCLE: ACTIONS OF } \\
\text { AUSTRALIA'S MAJOR PRODUCERS }\end{array}$ \\
\hline & & \\
\hline
\end{tabular}

